\title{
SPN Negative
}

National Cancer Institute

\section{Source}

National Cancer Institute. SPN Negative. NCI Thesaurus. Code C162069.

An indication that SPN expression has not been detected in a sample. 